Sympozjum

Rok XXIII 2019, nr 1(36), s. 119-142

\author{
ks. Janusz Królikowski \\ Uniwersytet Papieski Jana Pawła II w Krakowie \\ ORCID: 0000-0003-3929-6008; e-mail: jkroliko@poczta.onet.pl \\ https://doi.org/10.4467/25443283SYM.19.007.10636
}

\title{
MILCZENIE WOBEC TAJEMNICY BOGA I TEOLOGIA
}

\section{THEOLOGY AND THE SILENCE IN THE FACE OF THE MYSTERY OF GOD}

\begin{abstract}
Abstrakt
Tradycja chrześcijańska, czerpiąc inspirację z Biblii, podkreśla, że milczenie stanowi jeden z kluczowych elementów duchowości oraz procesu poznawczego w teologii. Zarówno więc tradycja, jak i dzisiejsze zmaganie się $\mathrm{z}$ „dyktaturą hałasu”, domagają się, aby na nowo uzasadnić potrzebę milczenia. W artykule zwracamy uwagę przede wszystkim na potrzebę powrotu do milczenia w teologii, ponieważ pozwala ona uchwycić wymiar tajemnicy zawarty w objawieniu Bożym oraz otworzyć się na mówienie Boga i na jego właściwe rozumienie, aby mogło dojrzeć do miłości, kontemplacji i adoracji. Chodzi więc o najbardziej właściwe postawy człowieka w stosunku do Boga.

Słowa kluczowe: milczenie, tajemnica, objawienie, poznanie, miłość, kontemplacja, adoracja
\end{abstract}




\begin{abstract}
Christian tradition, drawing its inspiration from the Bible, emphasises that silence constitutes one of the key elements of spirituality and the cognitive process in theology. Therefore, not only tradition but also today's struggle with the „dictatorship of noise" call for a renewed justification of the need for silence. In this article we highlight the need for the return to silence in theology, since it provides the opportunity to grasp the dimension of the mystery included in God's revelation and it helps us to open our ears to God's voice and to get the correct understanding of it so that it would grow to love, contemplation and adoration. Thus, it is all concentrated around the most appropriate attitudes of man towards God.

Keywords: silence, mystery, revelation, cognition, love, contemplation, adoration
\end{abstract}

„Światło, jakim Tajemnica obdarza,
zagęszcza jeszcze mrok, w którym ona się ukrywa”.

Henri de Lubac ${ }^{1}$

Milczenie i tajemnica pozostają ze sobą w najbardziej ścisłym związku. Mimo że kultura współczesna zdystansowała się bardzo w stosunku do milczenia i tajemnicy, ponieważ kładzie głównie nacisk na działalność, skuteczność i użyteczność materialno-techniczną, to jednak nie brakuje zarazem znaków powrotu do tych podstawowych rzeczywistości, współistotnych z naturą, życiem i rozwojem człowieka jako ducha wcielonego. Hałas wywoływany przez współczesną kulturę techniczną staje się nieznośny - mówi się nawet o „dyktaturze hałasu” - dlatego też nie brakuje coraz to nowych uzasadnień - może często są one jeszcze zbyt nieśmiałe - potrzeby ciszy, co sprawia, że już od jakiegoś czasu odradzają się

${ }^{1}$ H. De Lubac, Na drogach Bożych, tłum. A. Turowiczowa, Paris 1970, s. 107.

2 R. Sarah, N. Diat, Moc milczenia. Przeciw dyktaturze hałasu, tłum. A. Kuryś, Warszawa 2017. 
filozofia ${ }^{3}$ i teologia milczenia ${ }^{4}$. Wystarczy powiedzieć, że stało się niemal oczywiste, że milczenie stanowi integrującą część dialogicznej struktury człowieka, która - podobnie jak muzyka - składa się w swej istocie z dźwięków i pauz. Oczywiście, milczenie jako postawa duchowa nie odrodzi się bynajmniej łatwo, ponieważ dzisiejszy, powszechny nacisk głośno wypowiadanych, wręcz krzyczanych w każdej sprawie i w każdej sytuacji słów jest ogromny. Nie oznacza to jednak, że mamy się wycofać. W tym więc miejscu zamierzamy pokazać, że milczenie jest konstytutywnym elementem odniesienia się człowieka do tajemnicy Boga, a tym samym także elementem gnozeologicznym w teologii. Na tym tle będzie można sformułować propozycje o charakterze bardziej egzystencjalnym.

\section{Język ludzki i tajemnica}

Nie ulega wątpliwości, że człowiek ze swej natury jest istotą mówiącą (homo loquens). Wynika z tego, że jest on zdolny do nawiązania dialogu, do stawiania pytań i do dzielenia się tym, co poznał i czego doświadczył. Ta zdolność zakłada równocześnie, że konieczna jest także zdolność słuchania drugiego, aby móc poznawać i kochać. Bez słuchania jest niemożliwe spotkanie międzyosobowe, ponieważ bez niego dialog zamienia się w drętwy monolog, a w końcu staje się wyłącznie mówieniem o sobie, łatwo wpadającym w pychę. Słowo, zamiast być nośnikiem komunikacji międzyosobowej, staje się wówczas przeszkodą dla rozumienia ludzkiego.

Wewnętrzna więź między słowem, milczeniem i tajemnicą zawsze była przeżywana bardzo głęboko przez ludzi duchowych i mistyków, i to nie tylko w tradycji chrześcijańskiej, lecz także w tradycjach i religiach pozabiblijnych. Poeci i artyści czuli i niejednokrotnie w swoich wypowiedziach wskazywali na tę więź, dowodząc, że percepcja nie może ade-

3 Por. J. Rassam, Le silence comme introduction à la métaphysique, Toulouse 1980.

${ }^{4}$ Por. Kartuz, Miłość i milczenie, tłum. A. Żelechowska, Kraków 1987; C. DE Hueck Doherty, Milczenie. Doświadczanie milczenia Boga, tłum. K. Dudek, Kraków 2011; P. GABARA, Pojęcie milczenia i jego funkcja $w$ relacji między Bogiem a człowiekiem w homiliach Jana Pawła II, Kraków 2013. 
kwatnie wyrazić za pomocą ludzkich słów doświadczeń granicznych, których doznaje człowiek. Im bardziej jakieś doświadczenie dotyka człowieka i im głębiej sięga w głąb jego egzystencji, w miejsca, w których spotyka się duch i dusza, tym bardziej rośnie w człowieku świadomość, że nie może takiego doświadczenia zamknąć w swoich słowach, choćby najbardziej lotnych. Pojawia się wówczas potrzeba uciszenia głosów, mogących co najwyżej zakłócić doznawane niepowtarzalne doznania, stające się udziałem człowieka. Słowo w takim przypadku nie zostaje bynajmniej odrzucone, ale zachodzi potrzeba przekroczenia go przez wejście w sferę milczenia. Staje się ono bardziej wymowne niż jakiekolwiek słowo i każda inna forma ekspresji. Zwyczajny człowiek dochodzi do takiego wniosku najczęściej w odniesieniu do miłości.

Z takim doświadczeniem urzeczywistniającym się na poziomie bytu, drugiego człowieka i tajemnicy Boga ściśle łączy się wymiar kontemplacyjny. W nim człowiek odczuwa potrzebę zawieszenia głosu, by mógł przemówić w nim przedmiot poznania, a dzięki temu, by stało się możliwe zjednoczenie z nim. W przypadku słuchania głosu Boga, który przemawiał „wielokrotnie i na różne sposoby” - przez stworzenie, przez wydarzenia zbawcze, przez słowa proroków, a w końcu przez wypełnione objawienie w Jezusie Chrystusie (por. Hbr 1,1-2) - przechodzi w modlitwę i w adorację. Milczenie wewnętrzne stwarza "możliwość” słuchania słowa Boga, który mówi do człowieka, który go szuka i zachęca do nawiązania z Nim wspólnoty, aby wyrwać go spod nacisku materii i wprowadzić do świata ducha, aby przeprowadzić go z grzechu do łaski, aby w końcu wprowadzić go w wieczność.

Milczenie w swoim najwyższym znaczeniu religijnym zajmuje centralne miejsce zarówno w objawieniu biblijnym Starego i Nowego Testamentu, jak i dziejach teologii duchowości chrześcijańskiej. Począwszy od pierwszych ojców Kościoła ze Wschodu i z Zachodu, przez wielkich teologów średniowiecznych, przez mistyków okresu odrodzenia i baroku, aż do współczesnych mistrzów duchowości, milczenie było i pozostaje warunkiem spotkania ze świętą tajemnicą Boga oraz jej rozumienia na miarę ludzkich możliwości i potrzeby zbawienia. Chcemy więc w tym miejscu nie tyle zaproponować jakąś apologię milczenia, co raczej pokazać jego wartość duchową, w szczególności w dziedzinie religijnej 
i teologicznej. Chodzi o milczenie, które nie byłoby jakimś zamknięciem wobec świata, ale o formę wyrazu ducha ludzkiego, ponieważ zdajemy sobie sprawę, że samo milczenie nie jest - jak trafnie podkreślił Georges Gusdorf - „formą wyrazu szczególnie intensywną. Ma ono sens tylko w ramach istniejącej komunikacji jako przeciwwaga lub pieczęć języka, który się ukształtował. Jest milczenie ubóstwa i nieobecność, tak

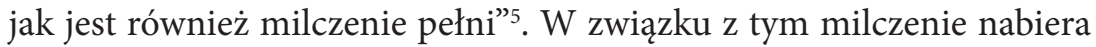
właściwego znaczenia wtedy, gdy „relacja ludzka czyni postępy wraz z innymi środkami aż do tego punktu doskonałości, w którym słowa stają się nieużyteczne. Milczenie nie posiada więc żadnej wewnętrznej siły magicznej - jest ono białą przestrzenią, w której mogą się manifestować harmonie zgodności lub istniejącej niezgodności. Milczenie nadaje głębię słowu".

Słowo jednak nie zawsze może być najlepszym środkiem wyrażenia siebie, czy też bezpośredniej komunikacji między osobami. Każdy doświadcza niewystarczalności słowa - słowa własnego i słów innych - w spotkaniu międzyosobowym, celem nawiązania doskonałej komunii opartej na zrozumieniu i jednoznaczności. Za G. Gusdorfem można powiedzieć, że "język może wyrazić tylko to, co zewnętrzne w bytach i w rzeczach. Odrzuca on radykalnie możliwość wyrażenia tego, co wewnętrzne, ponieważ każde słowo zmierza do uczynienia znanym (publication)" ". Często najlepsza cząstka człowieka pozostaje niewyrażona, ponieważ „każdy człowiek pozostaje dla innych tajemnicą” i dopiero w komunikacji wewnętrznej nawiązuje się „dialog bez słów”, „dialog ukryty", jedyny dialog o decydującej nośności. Ten rodzaj manifestacji jest nazywany „komunikacją pośrednią”, która jest „najprawdziwszą komunikacją między ludźmi”. Milczenie pozostaje w nim ostatnim słowem, ponieważ opisuje ono przestrzeń, do której nie dochodzą słowa.

Wprawne wykorzystanie „komunikacji pośredniej” spotykamy już u starożytnych mędrców i filozofów, na przykład u Sokratesa. Także

\footnotetext{
5 G. Gusdorf, La parole, Paris 1971, s. 89.

6 Tamże.

7 Tamże, s. 80.

8 Tamże, s. 81-82.
} 
Jezus oddziaływał swoją obecnością, która „oznaczała dla każdego z Jego zwolenników bezpośrednią i żywą relację bytu z bytem, a nieliczne słowa faktycznie wypowiedziane stanowią tylko odległe nawiązanie do tego faktu"9. Ponieważ słowa nie zawsze wprost zbliżają do prawdy osobowej, „bezpośrednie nauczanie nauczyciela mniej się liczy niż jego postawa”. Wówczas milczenie, jak często potwierdzają poeci, pisarze i mistycy, staje się „prawdziwsze niż słowo"10.

Jeśli zatem milczenie nie może istnieć bez słowa, to jest prawdziwe również stwierdzenie odwrotne, a mianowicie: słowo nie ma pełnego sensu i nie wywiera głębszego wpływu bez przestrzeni milczenia, które je poprzedza, towarzyszy mu i je niejako utrwala. Łatwo dostrzec, że więź słowa i milczenia, która pojawia się w języku ludzkim, nabiera szczególnego znaczenia $\mathrm{w}$ dziedzinie religii i teologii. $\mathrm{W}$ jej centrum sytuuje się słowo Boże ze swoją tajemnicą miłości, objawionej i ukrytej zarazem, które równocześnie mówi i milczy lub ukazuje się pod zasłoną. Słowo Boże przychodzi do człowieka z takim ciężarem, że jeśli nie byłby wspomagany przez łaskę, to nie byłby w stanie go unieść; człowiek czułby się nim przygnieciony, zostałby zredukowany do milczenia śmierci.

Do Mojżesza, który mówił na Synaju: „Spraw, abym ujrzał Twoją chwałę”, Bóg odpowiedział: „Nie będziesz mógł oglądać mojego oblicza, gdyż żaden człowiek nie może oglądać mojego oblicza i pozostać przy życiu" (Wj 33,18.20). Mojżesz został dopuszczony do prawdziwego oglądania Boga, ale tylko pośredniego: „A gdy cofnę dłoń, ujrzysz Mnie z tyłu, lecz oblicza mojego nie ukażę tobie" (Wj 33,23). Człowiek czuje bliskość śmierci, gdy słyszy słowo Boga wychodzące z Jego majestatu: „Jeśli jeszcze nadal będziemy słuchać głosu Pana, Boga naszego, pomrzemy" (Pwt 5,25).

\footnotetext{
9 Tamże, s. 82.

10 Tamże.
} 


\section{Milczenie adoracji}

Wielu współczesnych autorów, wychodząc z założeń racjonalistycznych, antropocentrycznych i pozytywistycznych, odrzuca nie tylko niewymowną tajemnicę Boga, lecz także boskość Jezusa Chrystusa jako osobowego objawiciela Boga. Niejednokrotnie dzieje się więc tak, że chęć powiedzenia niemal wszystkiego o Bogu, kończy się odrzuceniem Go jako przedmiotu teologii, która wówczas staje się co najwyżej dyskursem o sytuacji egzystencjalnej człowieka i kondycji duchowej dzisiejszego świata. Dokonuje się w ten sposób rozmycie samego pojęcia tajemnicy. Problem dotyka więc także teologię, która zarażona "wirusem” ateizmu, wycofuje się z zajmowania się tym, co najważniejsze, czyli tajemnicą Trójcy Świętej, objawieniem i zbawieniem dokonanym przez Słowo, które stało się ciałem, oraz przedłużaniem się Jego wcielenia w Kościele.

Do czasów najnowszych, w pełnej zgodności z biblijną wizją człowieka, teologia kościelna zawsze przyjmowała możliwość poznania Boga, oczywiście na gruncie objawienia i w mocy łaski Bożej. Nie było obce teologom stwierdzenie psalmisty: „W Twej światłości oglądamy światłość” (Ps 36[35],10). Bóg pozostaje jednak niewidzialny i niepoznawalny w sobie; pozostaje niezrozumiały i niewypowiedziany także w oglądzie uszczęśliwiającym nieba. Tajemnica Boga i adorujące milczenie człowieka nie ustają więc w chwale zbawionych, którzy przechodzą „od wiary”, czyli od „widzenia jakby w zwierciadle, niejasno" do widzenia "twarzą w twarz" (1 Kor 13,12; 2 Kor 5,7). Także w tym przejściu od „poznania niedoskonałego”, którym jest wiara na ziemi, do „poznania doskonałego”, które będzie miało miejsce w niebie (por. 2 Kor 5,7; Rz 8,24), tajemnica Boga pozostaje nieogarniona i niewyczerpana ${ }^{11}$. Także w niebie będzie prawdziwa intuicja św. Augustyna, który stwierdza syntetycznie: „Jeśli rozumiesz, to nie jest to Bóg - Si comprehendis, non est Deus"12. Podjął tę myśl św. Anzelm, stwierdzając: „Inteligencja ludzka rozumie racjonalnie, że Bóg jest niezrozumiały - Consideratio rationabiliter comprehendit

${ }^{11}$ Por. H. De LubaC, Na drogach Bożych, dz. cyt., s. 107-124.

12 Augustyn, Sermo 117, 5: PL 38, 663. 
incomprehensibile esse"13. Dzieje się tak z tej racji, ponieważ Ipse manet intra omnia, ipse extra omnia, ipse supra omnia, ipse infra omnia, jak sugestywnie i znacząco zapisał o Bogu św. Grzegorz Wielki ${ }^{14}$, o czym świadczy fakt, że to jego zdanie było wyjątkowo często cytowane przez teologów w okresie średniowiecza i znalazło się w wielu pismach mistycznych.

Przekonanie o niewymowności tajemnicy Boga i nieprzeniknioności Jego chwały odzwierciedla się wyjątkowo mocno w Boskiej komedii Dantego. Poeta, któremu najpierw towarzyszy Wergiliusz, a potem Beatrycze, przechodzi duchowo przez kolejne sfery niebieskie, wznosi się coraz wyżej, aby w końcu dojść do oglądania Boga. Część dzieła poświęcona rajowi, zaczyna się od wyznania:

Majestat wszystkich rzeczy Wzruszyciela

W przestwory wnika i na światów skronie

Ustopniowaną jasnością odstrzela ${ }^{15}$,

a kończy się wyznaniem „miłości, co wprawia w ruch słońce i gwiazdy”16. Opis doświadczenia duchowego Dantego otwiera się i zamyka bezpośrednim wyznaniem, że ani nie umie, ani nie może odpowiednio wypowiedzieć tego, co widział i kontemplował w Bogu:

W niebie, co sporzej bożych iskier chłonie,

Byłem; widziałem, czego nie wyświęci

Słowami człowiek, choć był w tamtej stronie.

Bo, przybliżony do celu swej chęci,

Rozum nasz tak w nim przepaściście ginie,

Że nie pociągnie za sobą pamięci ${ }^{17}$.

(...)

Dalej fantazja moja nie nadąży ${ }^{18}$.

13 Anzelm z Canterbury, Monologion 64: PL 158, 210. Por. Jan Pawee II, Encyklika Fides et ratio, Rzym 1988, 42.

14 Grzegorz Wielki, Moralia in Job 2, 12, 20: PL 75, 713.

15 Dante, Boska komedia [Raj, 1, 1-3], tłum. E. Porębowicz, Warszawa 1990, s. 333.

16 Tamże [33, 145], s. 490.

17 Tamże [1, 4-9], s. 333.

18 Tamże [33, 142], s. 490. 
Chociaż poeta może stanąć na progu tajemnicy Boga, oglądać światło i odczuć szczęście z tego płynące, niejednokrotnie zaznacza, że nie jest w stanie wyrazić całego piękna rzeczy widzianych i zachwytu, które one wywołują. Hans Urs von Balthasar trafnie zauważył w swoim komentarzu do Raju Dantego: „Dante może stwarzać w swym Raju już tylko wyobrażenia czystej światłości, miłości i szczęśliwości, oddzielając światłość od głębszej światłości, miłości i szczęśliwości, zastępując i podnosząc wartość miłości przez bardziej żarliwą miłość" ${ }^{19}$. Im bardziej myśl Dantego zwraca się do nieogarnionego oceanu światła Bożego, tym bardziej wzrasta w nim gorący zachwyt przeradzający się w intensywną kontemplację miłości.

Wobec tajemnicy Transcendencji człowiek, mimo iż posiada do dyspozycji język, zawsze intuicyjnie zdawał sobie sprawę z potrzeby przewartościowania brzmienia swojego głosu w tej sprawie, aż do powstrzymania się od wszelkich słów, aby nie sprofanować tej tajemnicy, a tym samym nawiązać bardziej bezpośrednią wspólnotę z Boskością. Także uznając wielkość objawienia Bożego, człowiek doszedł do zrozumienia, że absolutny Bóg nieskończenie przekracza każdą formę i każde pojęcie ludzkie i możliwość jakiegokolwiek wyrażenia przy pomocy ludzkich środków. Aby dojść do Niego, trzeba przekroczyć horyzont tego, co jest możliwe do zrozumienia zmysłowo i po ziemsku. Dlatego „we wszystkich religiach można zauważyć dystans w stosunku do słów i fascynację milczeniem. Słowo należy do hałasu świata, do wewnętrznych ograniczeń, definicji, determinuje i zamyka, wyraża prawo istoty i samo staje się prawem lub dyspozycją, rzeczą pozytywnie określoną"20. Stąd też pojawia się także w języku dążenie do przekroczenia granic przygodności i do wyzwolenia z jej ograniczeń. Stworzenie wzdycha za spotkaniem z tym, co nie posiada imienia, co nie jest już niczym ludzkim, co jest już tylko Całkowicie Innym.

${ }^{19}$ H. U. von Balthasar, Chwała. Estetyka teologiczna, t. 2: Modele teologiczne, cz. 2: Od Dantego do Peguy, tłum. E. Marszał, J. Zakrzewski, Kraków 2008, s. 76.

20 Tenże, Verbum caro. Skizzen zur Theologie I, Einsiedeln 1960, s. 135. 
Doświadczając spotkania z tajemnicą Boga - misterium tremendum, fascinosum i adorandum - człowiek odkrywa pozytywną funkcję milczenia. Może być ono uznane za „postawę mistyczną wobec niewymowności Bytu Najwyższego" ${ }^{21}$. W wizji chrześcijańskiej, począwszy od doświadczenia biblijnego do różnych rodzajów mistyki w czasie Kościoła, milczenie nie sprowadza się do pustki oddzielenia, głoszonej przez ascezę oczyszczającą buddyzmu, która nie zna Boga jako miłości stwórczej i odkupieńczej ${ }^{22}$. Celem milczenia religijnego w sensie chrześcijańskim jest natomiast osobowe spotkanie człowieka z osobową tajemnicą Boga, będącego pełnią miłości (por. $1 \mathrm{~J}$ 4,8). Dlatego, począwszy od starożytności, milczenie przyjmuje fizjonomię typowo religijną i teologiczną, staje się aktem kultycznym, oczyszczeniem etycznym i ofiarą wewnętrzną jest wypełnieniem wznoszenia się duszy do Boga.

Dla Dionizego Areopagity milczenie, podobnie jak pokój, jest istotnym przymiotem Boga: ,Jak on [Bóg] działa spokojnie i cicho, jak on jest w sobie i wewnątrz siebie"23, tego nikt nie jest w stanie ani pomyśleć, ani wyrazić. Tylko Bóg Trójca, będący „ponad substancją i ponad Boskością”, przekraczając nieskończenie to, co myśl ludzka może uchwycić i zrozumieć, może poprowadzić człowieka „w górę”, „na najwyższy szczyt tajemnic Pisma, gdzie proste, czyste i niezmienne misteria teologii kryją się w wyższej nad światło ciemności niezgłębionego milczenia" ${ }^{24}$. Milczenie staje się więc wymiarem dialektycznym, wzniośle mistycznym, objawienia Boga i Jego rozumienia ze strony człowieka. Milczenie zapala światło „W największej mroczności (...) nieskończenie napełnia niewidome intelekty blaskami przekraczającymi każde piękno"25.

Już w bezpośredniej epoce poapostolskiej, wraz ze św. Ignacym Antiocheńskim, stwierdza się jednoznacznie, że milczenie przekracza słowo, przekracza definitywne formuły słowne, do których w środowisku

21 N. Abbagnano, Dizionario di Filosofia, Torino 1971, s. 793 (hasło: Silenzio).

22 Por. H. DE Lubac, Aspekty buddyzmu, tłum. I. Kania, Kraków 1995, s. 35-88.

23 Pseudo-Dionizy Areopagita, Imiona boskie [11, 1], w: tenże, Pisma teologiczne, tłum. M. Dzielska, Kraków 2005, s. 309.

24 Tenże, Teologia mistyczna [1, 1], w: Tenże, Pisma teologiczne, dz. cyt., s. 325.

25 Tamże. 
chrześcijańskim czuło się pewne przywiązanie. Święty Ignacy w Liście do Efezjan napisał: „Lepiej jest milczeć i być, niż mówić i nie być. Dobrze jest uczyć, jeśli ten, kto mówi, działa. Jeden jest Nauczyciel, który rzekł i wszystko się stało, a to, co uczynił w milczeniu, godne jest Jego Ojca. Ten, kto posiadł prawdziwe słowo Jezusa, może słuchać także Jego milczenia, aby stał się doskonały i umiał działać przez swoje słowo i dać się poznać przez swoje milczenie. [Nic] nie jest zakryte przed Panem, lecz nawet nasze najgłębsze tajemnice są blisko Niego"26. Bóg objawił się za pośrednictwem swojego Syna, Jezusa Chrystusa, który „jest Jego słowem wychodzącym z milczenia"27. Działanie i milczenie Jezusa stają się więc przestrzenią dla słuchania głosu Ojca, aby móc się upodobnić do Jego Syna: „Abyśmy okazali się uczniami Jezusa Chrystusa, jedynego naszego Mistrza"28. Tym milczeniem i byciem dla św. Ignacego jest miłość, zakorzeniona w jedności Chrystusa z Ojcem, z której wypływa wiara i miłość chrześcijanina. Dzieła miłości dokonane przez Jezusa w czasie Jego ziemskiego życia, łącznie z milczeniem śmierci, są najbardziej wymownym nauczaniem, które przekazał, i wyrazem Jego misji zbawczej.

Zmagając się z herezją Eunomiusza św. Grzegorz z Nyssy broni niezrozumiałości Boga: „To, co nieskończone ze swej natury, nie może być zrozumiane za pośrednictwem żadnego pojęcia słownego. Majestat Boży nie ma granic ani nie może być opisany". Jeśli jednak nieskończony Bóg „przekracza wszelkie znaczenie imion”, jeśli „pod każdym względem to, co nieskończone, wymyka się wszelkim definicjom”, to „jakim imieniem obejmę to, co jest niezrozumiałe"? "Jakim głosem wypowiem to, co żadnym głosem nie może być wyrażone i wypowiedziane? Ponieważ zatem to, co boskie, jest lepsze i bardziej wyjątkowe niż wszelkie znaczenie semantyczne, nauczyliśmy się czcić milczeniem i adorować rzeczy, które przekraczają wszelki dyskurs i wszelką myśl’29.

${ }^{26}$ Ignacy Antiocheński, Do Kościoła w Efezie [15, 1-2], w: Pierwsi świadkowie. Pisma Ojców Apostolskich, tłum. A. Świderkówna, Kraków 1998, s. 117.

27 Tenże, Do Kościoła w Magnezji [8, 2], w: Pierwsi świadkowie, dz. cyt., s. 122.

28 Tamże [9, 2], s. 122.

29 Grzegorz z Nyssy, Contra Eunomium III: PG 45, 602. 
Mamy w tych pytaniach postawionych przez św. Grzegorza z Nyssy świadectwo „teologii negatywnej” (apofatycznej), którą w tradycji chrześcijańskiej zapoczątkował i wstępnie uporządkował już Klemens Aleksandryjski ${ }^{30}$. Przekonaniem o adoracji Boga za pośrednictwem milczenia są naznaczone wypowiedzi wszystkich ojców Kościoła wschodnich i zachodnich. Wystarczy wspomnieć Orygenesa, ojców kapadockich, św. Augustyna. Pod ich wpływem cała myśl chrześcijańska, aż do naszych czasów, będzie nosiła ten sam rys. Pojawia się oczywiście pytanie, czy „teologia negatywna” prowadzi do prawdziwego poznania niezrozumiałego Boga? Sięgnijmy jeszcze raz do św. Grzegorza z Nyssy, który tak odpowiada na to pytanie: „Jednakże umysł, który czyni postępy, w ciąglym rozwoju i doskonaleniu się dochodzi do zrozumienia rzeczywistości, osiąga stopień kontemplacji i wreszcie dostrzega, że Bóg z natury swej jest niewidzialny. Odrzuca więc wszelkie pozory, nie tylko te, które są zrozumiałe dla zmysłów, ale i te, które zdaje się ogarniać rozum, i wciąż zmierza ku temu, co głębsze, a wykorzystując wysiłki ducha, dociera do tego, co niewidzialne i niepoznawalne, i tam ujrzy Boga. Na tym bowiem polega prawdziwe poznanie tego, czego szuka, a prawdziwa wizja polega na zrozumieniu, że Bóstwo jest niewidzialne, przedmiot dociekań zaś przekracza wszelkie poznanie, otoczony ze wszystkich stron niemożliwością zrozumienia jak ciemnym obłokiem"31. Takie poznanie towarzyszyło Mojżeszowi na Synaju: „Mojżesz więc osiągnąwszy wyższy stopień poznania, wyznaje, że widział Boga w ciemnym obłoku i zrozumiał, że Bóstwo z natury przekracza wszelkie pojmowanie" ${ }^{\text {"32. }}$.

30 Por. S. Lilla, La teologia negativa dal pensiero classico a quello patristico e bizantino, „Helikon” 22-27 (1982-1987), s. 211-279, 28 (1988), s. 203-279, 29-30 (1989-1990), s. 97-186, 31-32 (1991-1992), s. 3-72.

31 Grzegorz z Nyssy, Życie Mojżesza [2, 162-163], tłum. S. Kalinkowski, Kraków 2009, „Źródła Myśli Teologicznej” 50, s. 68.

32 Tamże $[2,164]$, s. 69. 


\section{O niewymownym Bogu można i trzeba mówić}

W dziejach teologii i duchowości chrześcijańskiej jest niewielu myślicieli, którzy tak szeroko jak św. Augustyn podjęliby w swojej refleksji zagadnienie niezgłębionej tajemnicy Boga i Jego wiecznego Słowa, które stało się ciałem w Jezusie Chrystusie. Tajemnica wcielenia Słowa stanowi punkt wyjścia i ostateczny horyzont, który określa sedno augustyńskiej teologii i działalności pasterskiej. Naznaczony głęboko spotkaniem z tajemnicą Boga i wprowadzony w nią w sposób najbardziej osobisty, św. Augustyn poświęcił wszystkie swoje siły, aby ludzkimi słowami opisać niezgłębione bogactwa miłości Bożej, objawionej w Jezusie Chrystusie i rozlewającej się przez Ducha Świętego w Kościele i w świecie. W Wyznaniach znajdujemy wyjątkowe świadectwo napięcia duchowego, które charakteryzowało całe jego życie; możemy je oczywiście szerzej poznać także z wielu innych jego wypowiedzi. Wielkość tajemnicy Boga wzbudziła w św. Augustynie całkowicie wyjątkowy zapał do słowa, aby za jego pośrednictwem wyrazić to, co niewyrażalne.

Już na początku Wyznań i Komentarza do Ewangelii św. Jana, św. Augustyn pyta, czy o Bogu można mówić, czy też należy o Nim milczeć, skoro jest Bogiem niewymownym i niezrozumiałym ${ }^{33}$. Zdając sobie sprawę z tego, jak niewiele człowiek może powiedzieć o Bogu, stwierdza: „I cóż właściwie mówią ci wszyscy, którzy o Tobie mówić usiłują! Lecz biada, jeśli się o Tobie milczy! Choćby najwięcej wtedy mówił człowiek, niemową jest" ${ }^{34}$. Wszystko w człowieku i dokoła człowieka mówi o Bogu. Jeśli jednak „człowiek zmysłowy (...) nie pojmuje tego, co jest z Bożego Ducha” (1 Kor 2,14), to dlaczego powinien o Nim mówić? Święty Augustyn odpowiada: „Byłoby lepiej, jeśli moglibyśmy milczeć i mówić: to należy do wiary, tak wierzymy; nie możesz zrozumieć, jesteś mały; trzeba być cierpliwym". W oczach ignoranta byłaby to jednak wymówka (deficienti ista excusatio est) ${ }^{35}$. Potrzeba mówienia o Bogu jest więc

33 Augustyn, Wyznania [1, 4], tłum. Z. Kubiak, Warszawa 1992, s. 30; TEnże, Homilie na Ewangelie św. Jana [1, 1], w: Tenże, Homilie na Ewangelie i Pierwszy List św. Jana, tłum. W. Szołdrski, W. Kania, Warszawa 1977, „Pisma Starochrześcijańskich Pisarzy” 15, s. 27-28.

34 Tenże, Wyznania $[1,4]$, dz. cyt., s. 30.

35 Tenże, Sermo 117, 7: PL 38, 665. 
potrzebą głęboko ludzką, sytuującą się na poziomie wiary, która domaga się od wierzącego, aby ją przekazywał i jej bronił.

O Bogu trzeba więc mówić. Ale jak? O tym, kim Bóg jest w sobie (quid est), i o tym, kim jest dla mnie (quid mihi est), można mówić tylko w wierze. Krystalizuje się w tym przypadku aksjomat: Wierzymy, aby znać i rozumieć (credamus ut cognoscamus): „Wierzę, dlatego też mówię - Ty wiesz, Panie. (...) Nie będę się prawował z Tobą - z Tobą, któryś Prawdą jest. Nie chcę też karmić się złudzeniami, aby nieprawość moja nie kłamała samej sobie"36. Wpisanie zagadnienia mówienia o Bogu do dziedziny wiary, pozwala św. Augustynowi określić także sposób wykorzystania języka w tym mówieniu. Jest to przede wszystkim język uwielbienia: „O najwyższy, najlepszy, najmożniejszy, bezgranicznie wszechmocny, najbardziej miłosierny i najsprawiedliwszy, najgłębiej ukryty i najbardziej obecny, najpiękniejszy i najsilniejszy, zawsze istniejący a niepojęty!”37. Uwielbienie sprawia, iż Bóg zniża się do duszy i wnika w serce, dzięki czemu człowiek może powiedzieć: „Pobiegnę za tym głosem, pochwycę Ciebie, Panie!”38. By móc wzrastać w poznaniu Boga, potrzeba zatem wsparcia ze strony samego wiecznego Słowa, ponieważ Ono jest „pokarmem” człowieka; Ono staje się „mlekiem” karmiącym człowieka zdolnego do przyjęcia tego "pokarmu” (Ille cibus est, accipe lac ut nutriaris, ut sis validus ad capiendum cibum) ${ }^{39}$. W obliczu Boga i Jego poznawalności człowiek musi uznać się za „dziecko”, które potrzebuje jeszcze „mleka dziecięcego", jak nieopierzony ptak, który może wprawdzie latać, ale tylko lękając się ${ }^{40}$. Oznacza to wszystko, że Boga można poznać tylko w Bogu, że widzi się Boga w świetle Bożym i że można o Nim mówić, tylko nawiązując z Nim pewną „współnaturalność”, przyjmując sercem Jego Słowo ${ }^{41}$.

36 Tenże, Wyznania $[1,5], d z$. cyt., s. 31.

37 Tamże [1, 4], s. 29.

38 Tamże [1, 5], s. 30.

39 Augustyn, Homilie na Ewangelie św. Jana [1, 12], dz. cyt., s. 35.

40 Por. Tenże, Sermo 117, 16: PL 38, 670.

41 Por. J. Maritain, On Knowledge through Connaturality, „Review of Metaphysics” 4 (1950), s. 473-481. 
Ponieważ Bóg jest niewymowny, a cokolwiek można o Nim powiedzieć, nie jest niewymowne, człowiek musi uznać, że jego ignorancja odnośnie do Boga jest absolutnie większa niż nawet najbardziej lękliwe stwierdzenie, że się Go zna. Jeśli „milcząc, pomyślałoby się, że coś byłoby godne tego, co niewymowne" ${ }^{\prime 2}$, to jest także prawdą, że mówiąc, wyraża się bardzo nieadekwatnie niewyrażalność Boga. Bóg jest o wiele bardziej niewyrażalny, niż jesteśmy w stanie to sobie wyobrazić i wypowiedzieć. Święty Augustyn wie bardzo dobrze, że słowa ludzkie rozmywają się w wiecznym Słowie Boga objawionym w Jezusie Chrystusie:

„Na początku było Słowo, i Słowo było u Boga, i Bogiem było Słowo". Można zrozumieć niewymownie: nie zdarza się, by rozumiano za pośrednictwem słów ludzkich. Chodzi nam o Słowo Boże i mówimy, ponieważ nie rozumie się. (...) Jest bowiem pewna forma, forma nieuformowana, ale forma wszystkich rzeczy uformowanych. (...) Jest tak z tej racji, że jest Bóg, pod Nim są usytuowane wszystkie rzeczy. Mówimy, jak jest niezrozumiałe to, co zostało przeczytane, jednak zostało przeczytane nie po to, aby było zrozumiane przez człowieka, ale aby człowiek bolał, że nie rozumie i znajdując rzeczy, które mu przeszkadzają w rozumieniu, poruszył je celem zmierzania do uchwycenia niezmiennego Słowa. (...) Mówimy o Bogu, cóż więc jest dziwnego w tym, że nie rozumiesz? Jeśli rozumiesz, nie jest to Bogiem. (...) Zbliżyć się odrobinę myślą do Boga jest wielkim szczęściem, ale zrozumienie Go jest całkowicie niemożliwe $e^{43}$.

Droga wskazana przez św. Augustyna celem wzniosłego zbliżenia się do Boga, aby o Nim mówić, jest drogą miłości i opiera się na jej dynamice. Jej istnienie zostało w szczególny sposób naznaczone mistycznym doświadczeniem kontemplacji w Ostii. Tam Augustyn i Monika „wspólnie zastanawiali się nad tym, czym będzie wieczne życie zbawionych" ${ }^{\prime 4}$, dochodząc do następującego wniosku, w pełni ponadczasowego w swojej wymowie: „Doszliśmy do naszych dusz i przekroczyliśmy je,

\footnotetext{
42 Augustyn, Sermo 117, 7: PL 38, 665.

43 Tamże, 117, 3: PL 38, 662-663.

44 Augustrn, Wyznania [9, 10], dz. cyt., s. 266.
} 
aby dotrzeć wyżej, aż do krainy niewyczerpanej obfitości, gdzie na wieki karmisz Izraela pokarmem prawdy i gdzie życiem jest owa Mądrość, przez którą staje się wszystko, co kiedykolwiek było i co jeszcze będzie. Ona zaś sama nie staje się, lecz jest, jak była, i tak zawsze będzie. A raczej nie odnosi się do niej żadne «było» i żadne «będzie»; ona po prostu jest, albowiem jest wieczna, a w wieczności nie ma przeszłości i przyszłości. I gdy tak w żarliwej tęsknocie mówiliśmy o niej, dotknęliśmy jej na krótkie mgnienie całym porywem serca. Westchnęliśmy i zostawiając przy niej uwiązane pierwociny ducha, wróciliśmy do gwaru naszych ust, gdzie każde słowo zaczyna się i kończy - jakże odmienne, Panie, od Słowa Twego, które w samym sobie trwa, nie starzejąc się, a odnawiając wszystkie byty" 45 .

Dla św. Augustyna, który mógł napisać o sobie: „Nie jakimś mglistym uczuciem, ale stanowczym wyborem kocham Ciebie, Panie" ${ }^{\prime 46}$, droga miłości znajduje swoje zwieńczenie w radości „nowej pieśni” śpiewanej już w niebie, będącej najwyższym wyrazem rozpoznania i uznania wiecznej tajemnicy Boga. Dlatego też św. Augustyn w innym miejscu stara się opisać, na czym może polegać ta wieczna pieśń zbawionych:

Dobrze śpiewać Bogu, to znaczy wyśpiewywać wśród radości. Co to znaczy wyśpiewywać wśród radości? Zrozumieć ani słowami wytłumaczyć tego niepodobna, co śpiewa serce. (...) Także dźwięk rozradowania czasami oznacza, że w sercu rodzi się coś, czego wypowiedzieć niepodobna. A komu przystoi taka radość, jeśli nie Bogu? Ponieważ jest niewypowiedziany, wyrazić Go nie zdołasz. A jeśli nie zdołasz Go wypowiedzieć, a nie powinieneś milczeć, co ci pozostaje, jak nie to, aby wykrzykiwać z radości, aby serce twoje weseliło się bez słów, a niezmierzona wielkość radości nie była krępowana ograniczeniami sylab ${ }^{47}$.

45 Tamże, s. 267.

46 Tamże [10, 6], s. 284.

47 Augustyn, Objaśnienia Psalmów. Ps 1-36 [32 (2), 8], tłum. J. Sulowski, Warszawa 1986, „Pisma Starochrześcijańskich Pisarzy” 37, s. 302-303. 


\section{Milczeć, aby Bóg mógł mówić}

Dla św. Augustyna, podobnie zresztą jak dla całej tradycji teologicznej, nieuchwytna niezrozumiałość Boga powinna być odczytywana w odniesieniu do objawienia Bożego wypełnionego w Jezusie Chrystusie, czyli w Słowie, które stało się ciałem. Wieczne Słowo Boga, które od początku było u Boga i przez które wszystko się stało (J 1,1), stając się człowiekiem, wzięło na siebie ciężar ludzkiego ciała, okryło się jego zasłoną oraz mówiło widzialnie przez zasłonę ciała. Dwa teksty z Ewangelii św. Jana powracają jak refren w pismach św. Augustyna i w całej tradycji kościelnej, by potwierdzać niewymowność Boga i milczenie, którego domaga się Jego objawienie: „Boga nikt nigdy nie widział” (J 1,18) i „Kto Mnie widzi, widzi także i Ojca” (J 14,9). Jak trynitarne objawienie Boga skoncentrowało się i wyraziło w Jezusie, tak również - aby człowiek mógł adekwatnie mówić o Bogu i w końcu dojść do Niego - musi on przyjąć w sobie słowo Chrystusa jako słowo bezpośrednio odnoszące się do Boga.

Dla uwypuklenia wymowy tradycji Janowej warto w tym miejscu powołać się na św. Jana od Krzyża. Podobnie jak św. Ignacy Antiocheński i św. Augustyn zapisał on: „Jedno słowo wypowiedział Ojciec, którym jest Jego Syn i to Słowo wypowiada nieustannie w wieczystym milczeniu; w milczeniu też powinna słuchać go dusza"48. Jan od Krzyża wskazuje również na znaczenie milczenia $\mathrm{w}$ skupieniu wewnętrznym ${ }^{49}$ oraz uznaje je za jedną $\mathrm{z}$ „dwunastu gwiazd do korony najwyższej doskonałości" ${ }^{50}$. W Drodze na Górę Karmel zostaje wydobyta dodatkowo funkcja teologiczna adorującego milczenia: „O wiele więc korzystniej będzie ogołocić te władze [władze duszy - J.K.], pogrążyć je w milczeniu i w ciszy, aby Bóg do nich przemawiał" 51 .

Wielki mistyk widzi w tej postawie milczenia możliwość zrealizowania przez człowieka jego dążeń duchowych jako całkowitego ukierunkowania życia na Boga, o którym mówili już prorocy starotestamentowi,

${ }^{48}$ Jan od Krzyża, Zasady miłości [21], w: Tenże, Dzieła, tłum. B. Smyrak, Kraków 1986, s. 96.

\footnotetext{
49 Por. tamże [40], s. 97.

50 Tamże [77], s. 101.

${ }^{51}$ Jan od Krzyża, Droga na Górę Karmel [3, 3, 4], w: Tenże, Dzieła, dz. cyt., s. 309.
} 
na których się powołuje w swojej wypowiedzi. Ozeasz mówi: „Dlatego zwabię ją i wyprowadzę na pustynię, i przemówię do jej serca” (Oz 2,16). Młody Jeremiasz mówi bardzo podobnie: „Uwiodłeś mnie, Panie, a ja pozwoliłem się uwieść; ujarzmiłeś mnie i przemogłeś” (Jr 20,7). Droga „prorocka”, oznaczająca mówienie w imieniu Boga, którą odkrywa wierzący jako swoją drogę, aby wędrować w świetle Boga, wobec Jego niewymownej tajemnicy, jest tą drogą, o której już mówiliśmy, a jest nią droga miłości.

Sens teologiczny przytoczonych wypowiedzi został już wyrażony przez klasyczne stwierdzenie św. Augustyna: Verbo crescente, verba deficiunt $^{52}$. Gdy rośnie w nas Słowo Boże, tracą na znaczeniu nasze ludzkie słowa, dlatego trzeba robić miejsce dla wiecznego Słowa niewymownej miłości Boga, aby ubogie słowa mogły nabrać sensu, a życie mogło stać się aktem miłości w odpowiedzi na udzielającą się miłość Boga. „Wycofanie się" słowa ludzkiego (verba deficiunt) wobec niewyrażalnej tajemnicy Boga staje się - jak macierzyńskie łono Maryi - idealną przestrzenią przyjęcia płodnego Słowa Bożego, oblubieńczej dyspozycyjności w stosunku do Jego działania zbawczego. Wraz z Verbo crescente w sercu człowieka milczenie słowa ludzkiego przemienia się w najwyższe wyrażenie miłości, ponieważ takie milczenie nie jest milczeniem ubóstwa człowieka lub nieobecności Boga w nim, ale milczeniem obecności niezgłębionych bogactw Boga w ubóstwie ludzkiej kondycji. Tak zrozumieli to święci i uznawali to za klucz najbardziej autentycznej duchowości chrześcijańskiej. W najwyższym stopniu to odkrycie jest widoczne u mistyków. Cel życia chrześcijańskiego, ponadto, to znaczy „najwyższa doskonałość”, o której mówi na przykład św. Jan od Krzyża, nie polega na „zgłębianiu siebie”, ale zmierza ona do stania się przede wszystkim „pogłębieniem wiary”, ponieważ im bardziej postępuje się w doświadczeniu wewnętrznym opartym na wierze, tym bardziej wnika się także w głębię wiary. Doświadczenie chrześcijańskie nie jest ani nie może być w sobie „czystą wewnętrznością”, ale jest zasadniczo uczestniczeniem w „doświadczeniu Chrystusa” i w Jego rzeczywistości ${ }^{53}$.

52 Augustyn, Sermo 288, 5: PL 38, 1307; Sermo 120, 2: PL 38, 677. Por. Benedykt XVI, Adhortacja apostolska Verbum Domini, Rzym 2010, 66.

53 Por. H. De Lubac, Mistica e mistero cristiano, Milano 1979, s. 22-23. 
To, co zostało tutaj powiedziane, oznacza, że najbardziej właściwą treścią wiary chrześcijańskiej - w jej podwójnym akcie mówienia o słowie Bożym i w adorowaniu go w milczeniu tajemnicy - jest Jezus Chrystus, Słowo, które stało się ciałem, i jako takie jest pełną prawdą o Bogu w stosunku do człowieka oraz jedyną i niezastąpioną drogą, zarówno przychodzenia Boga do człowieka, jak i spotkania człowieka z najwyższą tajemnicą Boga. „Suma teologiczna” czwartej Ewangelii niejako syntetyzuje ruch zstępujący i wstępujący urzeczywistniany przez historyczną osobę Jezusa jako osobowego Objawiciela niewidzialnego Ojca i dawcy wiecznego zbawienia wszystkim ludziom: „Ja jestem drogą i prawdą, i życiem” (J 14,6). Jezus jest równocześnie niewymowną tajemnicą Ojca (por. J 1,18) i „ewangelią” odkupieńczego objawienia Boga w stosunku do ludzkości. Jak przypomina św. Paweł, ,jeden jest Bóg, jeden też pośrednik między Bogiem a ludźmi, człowiek, Chrystus Jezus, który wydał siebie samego na okup za wszystkich" (1 Tm 2,5-6). Aby zyskać dostęp do wiecznego Słowa Bożego, aby słuchać Go w Jego niewymowności, człowiek powinien przede wszystkim przyjąć Ewangelię Jezusa Chrystusa, ponieważ tylko On objawił widzialnie tajemnicę Ojca w konkretności swego życia ukrytego, począwszy od ukrycia w tajemnicy wcielenia aż do najbardziej niewymownego milczenia śmierci na krzyżu.

\section{Hymn milczenia}

Stając w wierze wobec najwyższej i najświętszej tajemnicy Boga, pełni bytu i miłości, wierzący odczuwa potrzebę milczenia w pełni religijnego, to znaczy wypełnionego adoracją, która wyrasta z miłości i poruszana miłością do Boga i do braci zostaje zwieńczona kontemplacją miłości Boga i poświęceniem się na rzecz braci. Modlitwa uwielbienia, która rozwija się jako „pieśń radości”, staje się wówczas najwyższym wyrażeniem niewymowności Boga. Objawienie Słowa urzeczywistnia się jako „tak rozległa nadobfitość i naduniesienie (hiperbole, perisseuein), że ze swej strony pozbawia słowa i tchu, a wypowiedź jest w stanie wyrazić się tylko dialektycznie: poznanie jako miłość przekracza samo poznanie"s4.

${ }^{54}$ H. U. von Balthasar, Verbum caro, dz. cyt., s. 155. 
W takim przypadku zarówno wierzący, jak i teolog, który rozważa słowo Boże w postawie modlitwy, czuje potrzebę skierowania do Boga właściwie jednego, syntetycznego wezwania, które znajdujemy na przykład u św. Ignacego Loyoli: „Daj mi tylko miłość Twoją i łaskę, a to mi wystarczy" 55 .

Tak pojęte doświadczenie chrześcijańskie odkrywa i afirmuje pozytywną funkcję milczenia, widząc jej potrzebę zarówno w celebracjach liturgicznych, jak i w teologicznym procesie poznawczym. Nie przypadkiem II Sobór Watykański podkreśla potrzebę uwzględnienia w czynnym uczestniczeniu w liturgii „świętego milczenia - silentium sacrum”: „W odpowiednim czasie należy zachować także pełne czci milczenie" ${ }^{25}$. Za tradycją apofatyczną Kościoła można także mówić o wymiarze kosmicznym milczenia, które pojawia się wtedy, gdy wierzący sięga do tajemnicy Boga, który jest ponad wszystkim, jak to znakomicie wyraża hymn św. Grzegorza z Nazjanzu:

O Ty, nad wszystko najwyższy! Bo jakże inaczej zwać Ciebie? Jakież słowo wysłowi? Słów braknie, by Ciebie wyrazić. Jakaż myśl Ciebie ogarnie? Daremny jest myśli wysiłek. Tyś jeden niewysłowiony, boś stworzył wszystko, co mówi;

Tyś tylko sam niepojęty, boś stworzył wszystko, co myśli.

Wszystko, co myśli i co nie myśli, cześć Ci oddaje,

Ku Tobie bowiem zmierzają powszechne wszystkich pragnienia I wszystkie boleści. Wszystko się modli do Ciebie. Wszystko, Uznając Twoje wyroki, hymn Tobie szepce milczący ${ }^{57}$.

Tajemnica Boga, objawiona mądrze i łaskawie człowiekowi, nadal pozostaje tajemnicą okrytą milczeniem (sesigemenu) (por. Rz 16,25). Ostatecznym celem życia chrześcijańskiego i spekulacji teologicznej pozostaje „zakorzenienie i ugruntowanie” w miłości, aby „ogarnąć duchem, czym jest Szerokość, Długość, Wysokość i Głębokość, i poznać miłość

55 Ignacy Loyola, Ćwiczenia duchowne, 234, tłum. J. Ożóg, Kraków 1997, s. 95.

56 II Sobór Watykański, Konstytucja o liturgii świętej Sacrosanctum Concilium, Rzym 1965, 30.

57 Grzegorz z Nazjanzu, Hymn do Boga, tłum. E. Grabowski, w: A. Bober, Antologia patrystyczna, Kraków 1965, s. 495. 
Chrystusa, przewyższającą wszelką wiedzę”, a w ten sposób zostać „napełnionym całą Pełnią Boga" (por. Ef 3,17-19). Także teolog, jeśli będzie trzymał się pierwszej zasady teologicznej, która mówi, że tajemnica Boga jest niewymowna zarówno w czasie, jak i w wieczności, będzie jasno czuł granice swojej spekulacji i swoich wypowiedzi, które zawsze pozostają tylko muśnięciem wiecznej tajemnicy. Nie oznacza to, że teologia jest nauką relatywną - jest nauką czującą swoje ograniczenia, a w ten sposób odkrywającą także swoją wielkość i znaczenie. Nie pozostaje to bez wpływu na inne dziedziny nauki, które także powinny rozwijać się w pokorze poznawczej, która powinna być cechą każdego prawdziwego intelektualisty i każdego uczonego, bez względu na uprawianą dziedzinę nauki. Tylko w ten sposób można uchronić się przed tym doświadczeniem, które opisuje Dante na początku Piekła:

W życia wędrówce, na połowie czasu,

Straciwszy z oczu szlak nieomylnej drogi,

W głębi ciemnego znalazłem się lasu ${ }^{58}$.

Możemy zakończyć prowadzone tutaj refleksje, odwołując się jeszcze raz do Dionizego Areopagity, który zaczyna swoją Teologię mistyczną od następującej modlitwy: „O Trójco, ponad substancją i ponad Boskością, i ponad dobrem! Przewodniczko chrześcijan w boskiej mądrości, prowadź nas w górę, ponad niewiedzę i światło, na najwyższy szczyt tajemnic Pisma, gdzie proste, czyste i niezmienne misteria teologii kryją się w wyższej nad światło ciemności niezgłębionego milczenia, która płonie najświetniejszym światłem w największej mroczności i będąc całkowicie nieuchwytną i niewidzialną, nieskończenie napełnia niewidome intelekty blaskami przekraczającymi każde piękno" ${ }^{59}$.

Święty Bonawentura przytoczył tę modlitwę na końcu swojego traktatu Wędrówka myśli do Boga, jakby w ten sposób chciał powiedzieć: „Taki jest Bóg" ${ }^{60}$. Niech temu sugestywnemu stwierdzeniu towarzyszy zatem

${ }^{58}$ Dante, Boska komedia [Piekło, 1, 1-3], dz.cyt., s. 25.

59 Pseudo-Dionizy Areopagita, Teologia mistyczna [1, 1], w: tenże, Pisma teologiczne, dz.cyt., s. 325.

${ }^{60}$ Św. Bonawentury „Droga duszy do Boga”, wstęp, przekład i objaśnienia S. C. Napiórkowski, w: Mistyka w życiu człowieka, red. W. Słomka, Lublin 1980, s. 157. 
także przestroga św. Leona Wielkiego: „Niechaj ludzka ułomność podda się chwale Bożej i niech się zawsze okazuje niezdolna do wyjaśnienia dzieł miłosierdzia Jego. Niechaj rozum nasz pracuje, niech wytęża się pomysłowość, ale niechaj zawodzi wymowa. Dobrze jest, by tak było nawet z tym, co słusznie myślimy o majestacie Boga" ${ }^{\prime 1}$.

\section{Bibliografia}

Abbagnano N., Dizionario di Filosofia, Torino 1971.

Anzelm z Canterbury, Monologion: PL 158, 142-224.

Augustyn, Homilie na Ewangelie i Pierwszy List św. Jana, tłum. W. Szołdrski, W. Kania, Warszawa 1977, „Pisma Starochrześcijańskich Pisarzy” 15.

Augustyn, Objaśnienia Psalmów. Ps 1-36, tłum. J. Sulowski, Warszawa 1986, „Pisma Starochrześcijańskich Pisarzy” 37.

Augustyn, Sermo 117: PL 38, 661-671.

Augustyn, Sermo 120: PL 38, 676-678.

Augustyn, Sermo 288: PL 38, 1302-1308.

Augustyn, Wyznania, tłum. Z. Kubiak, Warszawa 1992.

Balthasar H. U. von, Chwała. Estetyka teologiczna, t. 2: Modele teologiczne, cz. 2: Od Dantego do Peguy, tłum. E. Marszał, J. Zakrzewski, Kraków 2008.

Balthasar H. U. von, Verbum caro. Skizzen zur Theologie I, Einsiedeln 1960.

Benedykt XVI, Adhortacja apostolska Verbum Domini, Rzym 2010.

Bober A., Antologia patrystyczna, Kraków 1965.

Dante, Boska komedia, tłum. E. Porębowicz, Warszawa 1990.

Doherty C. de Hueck, Milczenie. Doświadczanie milczenia Boga, tłum. K. Dudek, Kraków 2011.

Gabara P., Pojęcie milczenia i jego funkcja w relacji między Bogiem a człowiekiem w homiliach Jana Pawła II, Kraków 2013.

${ }^{61}$ LeON Wielki, Sermo 29, 1: PL 54, 226. 
Grzegorz Wielki, Moralia in Job 2, 12, 20: PL 75, 713.

Grzegorz z Nyssy, Contra Eunomium: PG 45, 175-1122.

Grzegorz z Nyssy, Życie Mojżesza, tłum. S. Kalinkowski, Kraków 2009, „Źródła Myśli Teologicznej" 50.

Gusdorf G., La parole, Paris 1971.

Jan od Krzyża, Dzieła, tłum. B. Smyrak, Kraków 1986.

Jan Paweł II, Encyklika Fides et ratio, Rzym 1988.

Kartuz, Miłość i milczenie, tłum. A. Żelechowska, Kraków 1987.

Leon Wielki, Sermo 29: PL 54, 226-229.

Lilla S., La teologia negativa dal pensiero classico a quello patristico e bizantino, „Helikon” 22-27 (1982-1987), s. 211-279, 28 (1988), s. 203-279, 29-30 (1989-1990), s. 97-186, 31-32 (1991-1992), s. 3-72.

Loyola Ignacy, Ćwiczenia duchowne, tłum. J. Ożóg, Kraków 1997.

Lubac H. de, Aspekty buddyzmu, tłum. I. Kania, Kraków 1995.

Lubac H. de, Mistica e mistero cristiano, Milano 1979.

Lubac H. de, Na drogach Bożych, tłum. A. Turowiczowa, Paris 1970.

Maritain J., On Knowledge through Connaturality, „Review of Metaphysics” 4 (1950) s. 473-481.

Pierwsi świadkowie. Pisma Ojców Apostolskich, tłum. A. Świderkówna, Kraków 1998.

Pseudo-Dionizy Areopagita, Pisma teologiczne, tłum. M. Dzielska, Kraków 2005.

Rassam J., Le silence comme introduction à la métaphysique, Toulouse 1980.

Sarah R., Diat N., Moc milczenia. Przeciw dyktaturze hałasu, tłum. A. Kuryś, Warszawa 2017.

II Sobór Watykański, Konstytucja o liturgii świętej Sacrosanctum Concilium, Rzym 1965.

Św. Bonawentury „Droga duszy do Boga”, wstęp, przekład i objaśnienia S. C. Napiórkowski, w: Mistyka $w$ życiu człowieka, red. W. Słomka, Lublin 1980, s. 127-157. 
Ks. prof. dr hab. Janusz Królikowski - kapłan diecezji tarnowskiej; od 2014 roku dziekan Wydziału Teologicznego Sekcja w Tarnowie (UPJPII). W latach 1991-1996 studiował teologię na uczelniach rzymskich: Papieskim Uniwersytecie Świętego Krzyża (doktorat w 1995 roku), Papieskim Instytucie Wschodnim, Instytucie św. Tomasza Uniwersytetu Angelicum. W 2003 roku habilitował się w zakresie teologii dogmatycznej w Papieskiej Akademii Teologicznej w Krakowie. W latach 1996-2009 wykładał teologię w Papieskim Uniwersytecie Świętego Krzyża w Rzymie, a od 1997 roku wykłada teologię dogmatyczną na Wydziale Teologicznym Sekcja w Tarnowie. Od 2010 roku wykładowca mariologii w Instytucie Maryjno-Kolbiańskim „Kolbianum” w Niepokalanowie. Członek Polskiego Towarzystwa Mariologicznego, Towarzystwa Teologów Dogmatyków, Polskiego Towarzystwa Teologicznego Oddział w Tarnowie, członek zwyczajny Międzynarodowej Papieskiej Akademii Maryjnej w Rzymie. Autor licznych publikacji teologicznych. 